\title{
Spatial-Based Management of Van den Bosch Fortress to Revitalize Historical Assets and Develop Unique Cultural Tourism
}

\author{
Rara Sugiarti, Warto, and Supariadi \\ Lecturer at the Faculty of Culture Studies Sebelas Maret University, Indonesia \\ Researcher at Tourism Research Centre (PUSPARI) Sebelas Maret University, Indonesia \\ Corresponding Author: rarasugiarti@ staff.uns.ac.id
}

\begin{abstract}
ARTICLE INFO
ABSTRACT

Received

02 February 2020

Van den Bosch fortress is located in Ngawi East Java Indonesia. The

Accepted

12 March 2020

Available online

31 March 2020

fortress' unique location in the riverbanks of two main rivers of Java island, i.e. Bengawan Solo river and Madiun river, boosts its potentilas as a cultural tourist attraction. The meeting point between these two big rivers has given the fortress opportunities to develop unique tourism package. This study examined the potentials of the fortress, problems for developing the fortress, and the interconnection of spatial distribution of the fortress by employing geographic information system (GIS) to develop spatial-based management of the fortress as an intergrated cultural tourism site. Spatial-based management of the historical resource is aimed at combining and enhancing the urban elements including town square, traditional market, fortress, and rivers as well as some supporting facilities; and it is expected to be able to make Van den Bosch fortress as the center of the attractions. All of the elements of the urban area need to be spatially planned and managed in order to perform a unique tourist attraction in the most enticing historical destination of the region.
\end{abstract}

Keywords: cultural tourism, fortress, historical asset, spatial-based management.

\section{INTRODUCTION}

Historic sites, including fortresses, represent the life of a certain society during a certain era. Fortresses have great potentials to be developed as tourist attractions. Regardless the research findings by Loncarik (2013) mentioning that several fortresses are neglected and are not developed as tourist enticements, many fortresses have undergone this type of development. However, Xie (2006) mentions that despite a great potential to revitalize and develop a historic site stakeholders often encounter problems such as people's inaccurate perceptions, 
lack of support from industries, controversial use of facilities, lack of transparency on profit gain, as well as lack of authenticity. These identified problems imply the need of recommendation for future development and management plans.

Fortress is a great asset for the cultural tourism industry. Tourism is a resource industry which depends on the endowment of natural as well as cultural resources including heritage such as fortress. According to the World Tourism Organization, cultural tourism is one of the most promising and fastest growing types of tourism activities in the world. For example, the United States share of cultural tourism is up to $81 \%$ of total domestic tours. In European Union this share now makes $24 \%$ and according to expert estimates, it will reach $50 \%$ of total domestic tours in ten years (Kurbanova \& Gazalieva, 2014). Eldin, Fekry \& Menchawy (2013) wrote about Abu Qir Fortress and its significant role as a driving force in increasing tourism motivation and developing the community. This is in line with the previous research conducted by Caliskan (2010) which states that socio-cultural heritage may draw tourists to visit an attraction to enjoy entertainment, learn the significance of historic places, and view historic buildings or ruins of buildings. However, fortress http://ojs.unud.ac.id/index.php/eot tourism has not been able to be developed to its maximum potential because of poor management, limited facilities, and the lack of attractive activities for tourists (Loncarik (2013).

$$
\text { According to Ansari, }
$$

Mahdavinejad \& Abedi (2012) tourists visit historic or cultural sites for a variety of reasons which vary from seeking authentic cultural experiences to simply following the tour itinerary set up by the operator. Furthermore, Ballesteros \& Ramirez (2007) mentions that to develop heritage tourism there should be a step to convert the existing heritage into a tourism resource. Conversion of heritage into tourism resource has the potentials to create job opportunities, boost local economy, and improve commmunity welfare (Ismail, 2014).

Indonesia has diverse heritages representing the cultural wealth of the nation in the past. Indonesian history can be traced and learned from the heritages. One of them is fortress which performs the course of history of the Indonesians' life up to the present time. Indonesian fortresses were built by the Dutch Colonial Government during their colonial era in Indonesia. Therefore, fortresses have a close relationship with the long history of the Ducth colonial era in Indonesia for 350 years (Rukmana, 2015). Based on the historical record there are 459 fortresses 
spread in Indonesia, 303 of which are found in Sumatera, 159 in Java, 134 in Sulawesi, 12 in Bali-NTB-NTT, and 9 in Kalimantan. However, only 177 fortresses can be identified (GRAC, 2012). Fortress represents high spirit of the nation (Indonesian) to fight the colonizer, get rid of them, force them to leave the country, and get freedom from the colonial government.

Van den Bosch Fortress is one of the fortresses found in Indonesia. The existence of the fortress has given alternative choices for tourists visiting the region. This study aims to examine the potentials of Van den Bosch Fortress, the problems to develop the fortress, and the planning and management of the fortress seen from all of its internal parts as well as its connection with all of the town elements including traditional market, town square, rivers, hotels, restaurants, and travel agents.

\section{RESEARCH METHODS}

\section{Data}

Van Den Bosch Fortress is located in Ngawi East Java Indonesia. It took six years to build the fortress, from 1839 to 1845. The name Van den Bosch was taken from the name of Governor General Van den Bosch who was in charge of governing Indonesia during the Dutch http://ojs.unud.ac.id/index.php/eot colonial era. Van den Bosch Fortress has been open to public since 2011. Previously it was only for military use. People are now allowed to visit the site for tourism and recreational purposes. Tourists visiting the site can enjoy various attractions including the colonial building and green scenery in its surroundings. Several archaeological remains were found in the site, including fragments of earthenware, metal fragments, glass fragments, fragments of bone, and fragments of shells (Chawari, 2016). As a historic place Van den Bosch Fortress is protected by Law (Act No. 11/ 2000) about Cultural Heritage. According to the Law the Indonesian Government and all people can use the cultural heritage for religious, social, educational, scientific, technological, cultural, and tourism purposes.

The area consists of several parts including moat, dyke, drawbridge, residential area (house of governor), office room, kitchen, prison, ammunition storeroom, meeting room, sauna bathroom, fortress well, stage, swimming pool, and drainage. Table 1 mention parts of the physical building in the area of Van den Bosch Fortress as well their location and function. 
Table 1. Physical Components of Van den Bosch Fortress.

\begin{tabular}{|c|c|c|c|}
\hline No. & Components & Location & Function \\
\hline 1. & Moat & $\begin{array}{l}\text { Surrounding } \\
\text { the fortress }\end{array}$ & $\begin{array}{l}\text { Security, } \\
\text { defense }\end{array}$ \\
\hline 2. & Dyke & $\begin{array}{l}\text { Surrounding } \\
\text { the fortress }\end{array}$ & $\begin{array}{l}\text { Security, } \\
\text { defense }\end{array}$ \\
\hline 3. & Drawbridge & $\begin{array}{l}\text { Across the } \\
\text { moat in front of } \\
\text { the main gate }\end{array}$ & $\begin{array}{l}\text { Security, } \\
\text { defense }\end{array}$ \\
\hline 4. & $\begin{array}{l}\text { House of } \\
\text { Governor } \\
\text { General Van } \\
\text { den Bosch }\end{array}$ & $\begin{array}{l}\text { At the center of } \\
\text { the fortress' } \\
\text { right wing }\end{array}$ & $\begin{array}{l}\text { Residence of } \\
\text { Governor } \\
\text { General Van } \\
\text { den Bosch }\end{array}$ \\
\hline 5. & $\begin{array}{l}\text { Office } \\
\text { Rooms }\end{array}$ & $\begin{array}{l}\text { At the center of } \\
\text { the fortress' } \\
\text { left wing }\end{array}$ & $\begin{array}{l}\text { Carrying out } \\
\text { administrations }\end{array}$ \\
\hline 6. & Kitchens & $\begin{array}{l}\text { Behind the } \\
\text { house of } \\
\text { Governor } \\
\text { General Van } \\
\text { den Bosch }\end{array}$ & $\begin{array}{l}\text { Provision of } \\
\text { logistics }\end{array}$ \\
\hline 7. & Prison & $\begin{array}{l}\text { At every corner } \\
\text { of the fortress } \\
\text { (under every } \\
\text { staircases) }\end{array}$ & $\begin{array}{l}\text { Carrying out } \\
\text { punishments }\end{array}$ \\
\hline 8. & $\begin{array}{l}\text { Ammunition } \\
\text { Storeroom/Po } \\
\text { wder } \\
\text { Magazine }\end{array}$ & $\begin{array}{l}\text { On the left } \\
\text { wing of the } \\
\text { fortress (at the } \\
\text { front and back) }\end{array}$ & $\begin{array}{l}\text { Ammunition } \\
\text { storage }\end{array}$ \\
\hline 9. & $\begin{array}{l}\text { Communal } \\
\text { Baths }\end{array}$ & $\begin{array}{l}\text { On the right } \\
\text { wing of the } \\
\text { fortress (at the } \\
\text { front and the } \\
\text { back) }\end{array}$ & Bathing area \\
\hline 10. & $\begin{array}{l}\text { Meeting } \\
\text { Room }\end{array}$ & $\begin{array}{l}\text { On the left } \\
\text { wing of the } \\
\text { fortress (at the } \\
\text { front) }\end{array}$ & $\begin{array}{l}\text { Carrying out } \\
\text { meetings }\end{array}$ \\
\hline 11. & Sauna Bath & $\begin{array}{l}\text { At the back of } \\
\text { the fortress' } \\
\text { right wing }\end{array}$ & $\begin{array}{l}\text { Sauna bathing } \\
\text { area for } \\
\text { Governor } \\
\text { General Van } \\
\text { den Bosch }\end{array}$ \\
\hline 12. & Fortress Well & $\begin{array}{l}\text { Behind the } \\
\text { Office Rooms }\end{array}$ & Water source \\
\hline 13. & $\begin{array}{l}\text { Stage/Platfor } \\
\mathrm{m}\end{array}$ & $\begin{array}{l}\text { In front of the } \\
\text { fortress }\end{array}$ & $\begin{array}{l}\text { Entertainment } \\
\text { and recreation } \\
\text { area }\end{array}$ \\
\hline 14. & $\begin{array}{l}\text { Swimming } \\
\text { Pool }\end{array}$ & $\begin{array}{l}\text { In front of the } \\
\text { Stage }\end{array}$ & Recreation are \\
\hline 15. & $\begin{array}{l}\text { Swimming } \\
\text { Pool } \\
\text { Drainage }\end{array}$ & Near the pool & $\begin{array}{l}\text { Pool water } \\
\text { disposal systen } \\
\text { which ends in } \\
\text { Bengawan Solc } \\
\text { River }\end{array}$ \\
\hline
\end{tabular}

Source: Researchers' Interview \& Observation, 2017.
The location of Van den Bosch Fortress is in the meeting point between Bengawan Solo river and Madiun river. It is also close to the other elements of the town including traditional market, town square, and government office complex (See Figure 1).

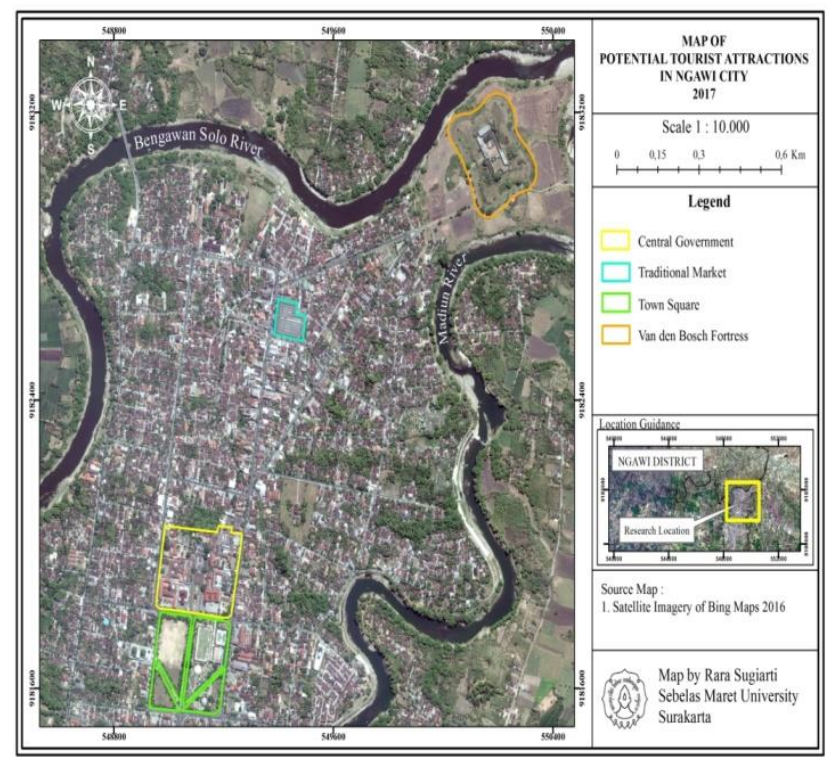

Figure 1. Map of Tourist Attractions of Ngawi City.

\section{Methods}

This research was carried out in Ngawi East Java Indonesia where Van den Bosch Fortress is located. The research employed spatial analysis which emphasizes the process of turning raw data into useful information with the objective of solving scientific or decision making problems (Goodchild, 2016). It was conducted by collecting spatial data concerning urban elements found in the town, especially the fortress, town square, traditional market, and rivers which are 
spatially distributed in Ngawi by employing Geographic Information System (GIS). The results of the GISbased mapping was utilized to describe the overall picture of Van den Bosch Fortress including its potentials, problems, and spatial constellation in the region. The spatial data were analyzed by studying all aspects of tourism facilities which support the enhancement of heritage and cultural attractions found in the area.

This study is a descriptive research referring to an objective representation of a historic site in Ngawi which is under investigation. This research made use of qualitative data obtained from two different sources including primary and secondary data sources. Primary data sources consisted of observation and semistructured interview which was utilized to acquire the key informants' and the tourists' perceptions, attitudes, and experiences on their visit to Van den Bosch Fortress. It was aimed at acquiring a first hand view of Van den Bosch Fortress and obtaining a deeper understanding about the place, people, and culture found in the area. The study involved managers, visitors, and government officials of the Ngawi Regency, especially the office of Tourism, Youth and Sports. The second was secondary data sources which consist of previous studies and government documents on Van den Bosch Fortress http://ojs.unud.ac.id/index.php/eot development. Since the research does not make any generalization from samples to population, the method applied is relevant. In this type of research quality of data in the form of useful information obtained from key informants is more important than representativeness of samples (de Vaus, 1995).

The research also employed interactive analysis to look at the management of Van den Bosch fortress. There are three important steps in the analysis including data reduction, data display, and conclusion drawing (Miles \& Hubermann, 1984). In the first step all data concerning the potentials and problems of Van den Bosch Fortress management were collected and reduced by selecting the appropriate data. Secondly, the data were displayed in various forms such as maps, tables, graphs, or charts to facilitate the whole process of the analysis. Finally, based on data which were collected, reduced, and displayed, a conclusion was made to perform the results of the analysis about Van den Bosch Fortress management. 


\section{RESULTS AND DISCUSSION}

\section{The Potentials of Van den Bosch Fortress as a part of the town vital assets}

Van den Bosch Fortress is one of the few fortresses in Indonesia which still maintains its physical buildings. Although many parts of the fortress are damaged, its original features can still be clearly seen from the ruins. Some researches mention that ruins of several historic buildings become famous tourist attractions (Ansari, 2012; Carisson \& Walden, 2010; Mansyur, 2008).

Van den Bosch Fortress is a part of the town vital assets. There are several places which support the development of Van den Bosch Fortress as a tourist attraction. Some of them are traditional market and town square. Several facilities including hotels, restaurants, travel agents, mosques, hospitals, banks also serve as essential parts of tourism development (Kurbanova, A.M. \& Gazalieva, N.I., 2014). In the context of tourism management, all of them function to create a high level of tourist satisfaction. Moreover, their presence can enhance the develeopment of tourism in Van den Bosch Fortress.

Besides its function to foster educational tourism by providing a lesson on the nation's history of patriotism, the http://ojs.unud.ac.id/index.php/eot fortress has a great potential to be developed in the context of other special interest tourism, specifically historical and cultural tourism. Goyal (2014) mentioned that educational tourism is a way to give the best education to students across the globe. Moreover, Kuo (2002) argued that promoting adequate understanding through tourism interpretation of the attraction to visitors is essential in developing educational tourism. Therefore, developing Van den Bosch Fortress as educational tourism site needs to be equipped with adequate interpretation services. Interpretation is a way of providing tourists with explanation about the site they visit in order that they know, understand, appreciate, and take part in conserving the resources (Kuo, 2002).

The geographical location of Van den Bosch Fortress serves as one of its most unique features. It was conveniently built near the confluence of Bengawan Solo River and Madiun River to defend the territory and oversee the river trade routes. Furthermore, its location offers attractive prospects for the development of unique water-based tourism activities such as canoeing, during which a guide will be giving explanation about the correlation between the rivers and the fortress itself, providing tourists with a high quality interpretation. Efforts in developing such attractions which go in line with tourist 
motivation have been explored in the work of Dunkley, Morgan \& Westwood (2011) on fortress tourism. They present the importance of thoroughly recognizing the purpose of an attraction and knowing what motivates tourists to visit the destination. The availability of a destination's newest offers and services greatly influence tourist motivation.

Another potential attraction that can be exploited from Van den Bosch Fortress is the burial site of $\mathrm{K}$. H. Muhammad Nursalim, a local Islamic figure who was a follower of Pangeran Diponegoro, a national hero who fought against the Colonial Dutch in Ngawi and the surrounding areas. Nursalim's storyburied alive because no weapons could kill him — serves as intriguing information for tourists that also portrays the locals' patriotism during the times of war. This local wisdom creates a unique value for the fortress. Kurbanova \& Gazalieva (2014) mentioned that the uniqueness of a tourist attraction plays a big role in attracting visitors. Besides, it creates a high level of tourist experience (Kurniawan, 2015; Ismail, 2014; Loncarik, 2013).

\section{Problems of Managing and Developing Van den Bosch Fortress}

Many fortresses across the globe face similar issues in their management and development. Van den Bosch Fortress is one of them. A research by Garača, Jovanovic \& Pejovic (2011) presented the issues faced by Petrovaradin Fortress, namely how to design a suitable spatial planning as well as how to manage and develop the area to the maximum extent. In the case of Van den Bosch Fortress, there are some problems regarding assets management, authority of management, low quality of human resources, and lack of knowledge of best practice tourism management. Stanojlovic, Ivkov-Dzigurski \& Dragin (2010) underlined the lack of tourism interpretation in fortress tourism. Besides, assets and authority issues are also a complicated matter and still remain unresolved despite the many discussions involving local and national stakeholders. Consequently, these issues hamper the management and development of the fortress.

Low quality of human resources is also problematic since sufficient basic knowledge about the fortress architecture, political roles, and the fortress history is required to develop a better management. Human resource competence in providing interpretation plays a significant role (Kuo, 2002). This is because the biggest e-ISSN: 2407-392X. p-ISSN: 2541-0857 
challenge in historic tourism lies in the ability to reconstruct the past in the present through interpretation. Interpretation does not only explain historic facts but also provide understanding about places, creates emotional response, and increases enjoyment, appreciation, and awareness (Stanojlovic, Ivkov-Dzigurski \& Dragin, 2010). It functions as a means of enhancing cross-cultural understanding, improving the quality of tourist experience, and performing effective management and conservation of the heritage sites (Garaca, Jovanovic \& Pejovic, 2011; Kuo, 2002). The lack of interpretation of Van den Bosch Fortress reduces the appreciation of visitors on the historic resource.

Van den Bosch Fortress is now in the phase of development planning. The planning concept includes spatial planning for the historic and cultural resources. Spatial planning is an important aspect of tourism development that corresponds with visitor and attractions management (Nahuelhual, et.al, 2013; Mirsanjari, 2012; Gunn, 1994). Lack of planning often results in lack of sufficient management, including management of attractions as well as management of visitors (Nahuelhual, Carmona, Lozada, Jaramillo \& Mauricio, 2013; Maksin \& Milijic, 2010). The planning concept for Van den Bosch Fortress development is done on http://ojs.unud.ac.id/index.php/eot collaboration among stakeholders including Ngawi Tourism Office, East Java Office of Archeology, and Yogyakarta Office of Archeology.

Developing Van den Bosch Fortress for special interest tourism destination requires holistic planning, including planning to utilize the spaces. A previous research by Garača, Jovanovic \& Pejovic (2011) on fortress tourism highlights the role of spatial planning in developing Petrovaradin fortress as a tourist attraction by determining its central functions and dividing its spatial entities. The development and management of fortress tourism activities will become easier and more effective with a suitable spatial planning. The importance of spatial planning conception in fortress tourism management is also present in the work of Rukmana (2012), where the various functions of the rooms of Vredeburg Fortress in Yogyakarta Indonesia are underlined. One of them functions as a museum, an attraction that is expected to meet the newest trends of tourism in the way that it is no longer just a place to store items with historical, scientific, artistic, or cultural values, but also a place which holds recreation and educational functions.

$$
\text { Spatial management and }
$$
development of fortresses as a tourist attraction also requires supporting digital services which also act as mobile tourist 
guide. Carisson \& Walden (2010) underlined how the use of mobile tourist guide of Bomarsund Fortress is very helpful in promoting the offered tourist attractions, its history, as well as its physical structure and layout.

Even though the number of tourists visiting Van den Bosch Fortress is still limited, the management needs to think about its carrying capacity. This is because spatial management of a fortress must take the location's carrying capacity into consideration. Jovicic \& Dragin (2008) mentioned that applying the concept of carrying capacity allows management to effectively and efficiently estimate the suitable level and direction of change that tourism will bring to the area.

Another problem is the lack of promotion for Van den Bosch Fortress. Since promotion plays an important role to draw tourists, the lack of promotion often results in public's ignorance. Adequate and responsible promotion is also a key factor behind the management and development of fortress tourism (Kurbanova \& Gazalieva, 2014).

Currently, the use of Van den Bosch fortress as learning sources and character building media is still limited. This is different from other fortressess such as Vredeburg fortress in Yogyakarta and Van Der Wijck fortress in Kebumen Centra Java. A study by Kurniawan (2015) http://ojs.unud.ac.id/index.php/eot noted the shift in the role of Van Der Wijck Fortress to become media for educating students and visitors about history. Fortresses are a great source of education, which calls for proper maintenance and conservation of their physical aspects. This is in line with a research undertaken by Marina, Muntean \& Stefani (2009) which underlined the important role of Alba Iulia Fortress as a means of teaching history to students. Fortresses have the significant role in educating visitors.

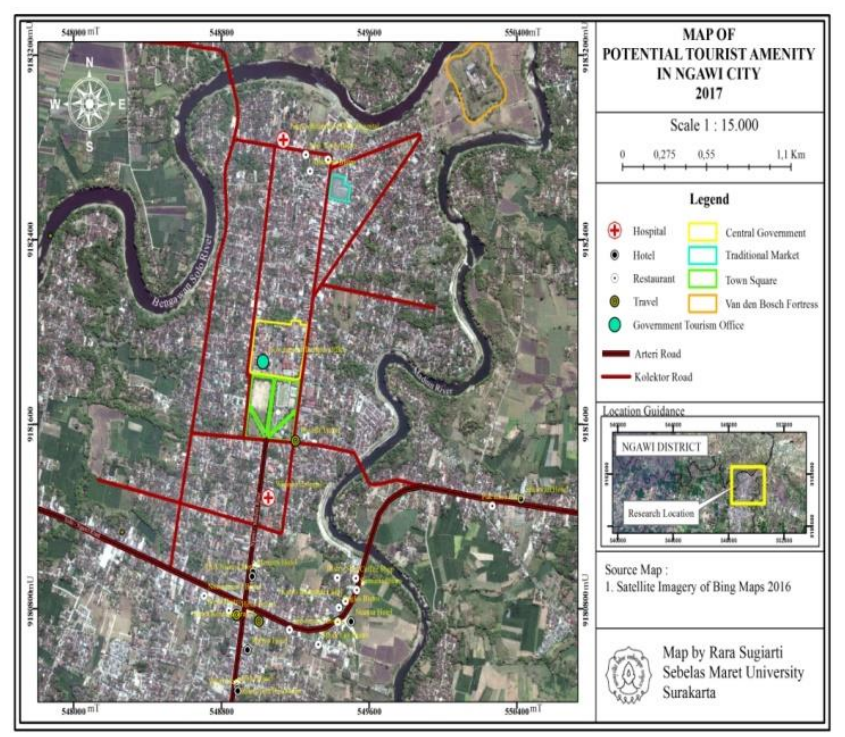

Figure 2: Map of Tourist Attractions and Amenities of Ngawi City.

\section{Spatial Based Management of Van den Bosch Fortress}

The management of Van den Bosch Fortress should be viewed from two aspects: internal management, which manages the physical construction of the fortress and all its internal aspects, and external management, which manages the 
fortress as a part of a bigger system, namely the spatial plan of Ngawi Regency. Previous studies mention that a tourist attraction cannot survive without creating synergy with its surrounding facilities; therefore considering the external factors is crucial (Garača, Jovanovic \& Pejovic, 2011; Marina, 2009).

\section{Internal Management}

Internal management covers the spatial management of the inner scope of the fortress, such as its facilities and physical architecture. It is aimed at optimizing its role in the educational context, specifically a lesson on the history of national patriotism intended to build character in Indonesia's young generation. Current management of Van den Bosch Fortress is still focused on physical features such as providing trash bins and outdoor ornaments placed at the corners of the structure. It is clear that the situation is not optimal, considering also the lack of management for non-physical aspects such as tourism interpretation of the fortress. This is problematic since interpretation is a means of providing visitors with information and knowledge about the attraction they are enjoying in order that they can appreciate it (Dzigurski \& Dragin, 2010; Kuo, 2002).

http://ojs.unud.ac.id/index.php/eot

\section{External Management}

External management is based on the need to create synergy with other components of the city that supports the development of a tourism package in which Van den Bosch Fortress is the core attraction. These supporting components are Pasar Besar Ngawi (a traditional marketplace), Alun-alun Merdeka Ngawi (town square), as well as Bengawan Solo and Madiun Rivers. Pasar Besar Ngawi provides souvenirs and local specialties of the town, specifically jajanan pasar (street food) and snacks. Alun-alun Merdeka Ngawi is strategically located at the heart of the town, about one kilometer away from the fortress, where a culinary center is built to promote various food and drinks from Ngawi. A management that is based on the fortress' interconnectivity with the town's other facilities has not been applied in developing this tourism package, even though according to Dede \& Ayten (2012), it is an essential aspect in the spatial management and planning of a tourism asset.

\section{CONCLUSION}

Van den Bosch fortress has the potentials to be developed as unique cultural tourist attraction. It is a historical monument of great importance which has diverse attractive historic parts including 
the main building of the fortress, the main yards, and the environment surrounding the fortress building. In order to revitalize the fortress it needs to be well managed for a wider function including function for sustaining the resource, educational function, ecological function, and economic function. This is in line with the results of some previous researches conducted by Kurbanova \& Gazalieva (2014) and Marina, et.al (2009) which highlighted multifunction of fortresses.

Apart from the abundant potentials of Van den Bosch Fortress, there are still limited development actions due to several problems including the lack of management planning. This has resulted in the absence of appropriate management for the resource. Besides, it has caused the following problems such as lack of promotion and lack of professional human resources. This conclusion supports the findings of research by Garaca, Jovanovic \& Pejovic (2011) which highlighted the importance of tourism spatial based management and design for developing cultural tourism. Another problem is limited facilities provided in the fortress, including interpretation facility which is useful to give adequate educational messages and information to create a better understanding about the fortress and enhance visitors' appreciation.
Spatial based management is one of solutions to several problems of Van den Bosch Fortress tourism development. This supports the research undertaken by Dede \& Ayten (2012) and Garaca, Jovanovic \& Pejovic (2011) concerning spatial planning for better management. Revitalization of Van den Bosch Fortress, which is focused on planning the rehabilitation of the physical building of the fortress, has been initiated by the local government. Furthermore, the revitalization of the fortress needs to be supported by empowering best practice management of all related resources including human resources, urban resources, and natural resources.

\section{ACKNOWLEDGEMENT}

This work was supported by the Directorate of Research and Community Service, Directorate General of Research and Development, Ministry of Research, Technology, and Higher Education of the Republic of Indonesia (Grant No. 098/SP2H/LT/DRPM/IV/2017).

\section{REFERENCES}

Ansari, M., Mahdavinejad, M. \& Abedi, M., 2012, The Role of Historic and Heritage Wealth in Sustainable Tourism Development, Asian Journal of Social Sciences and Humanities Vol. 1(3), pp. 70-77. 
Ballesteros, E. R. \& Ramirez, M.H., 2007, Identity and Community Reflections on the Development of Mining Heritage Tourism in Southern Spain, Tourism Management Vol. 28, pp. 677-687.

Caliskan, V., 2010, Examining cultural tourism attractions for foreign visitors: the case of Camel Wrestling in Selcuk (Ephesus), Turizam Vol. 14(1), pp. 22-40.

Carisson, C. \& Walden, P., 2010, Supporting tourists at the Bomarsund Fortress with a mobile value service, Journal of Information Technology Theory and Application Vol. 11 (1), pp. 43-56.

Chawari, M., 2016, Benteng Van den Bosch, Ngawi: Temuan artefaktual sebagai cerminan alat-alat kebutuhan sehari-hari, Arkeologi Vol. 36(2), pp. 195-210.

Dinca, Iulian, et.al, 2010, Touristic culture through identification of the visitor with events and natural and built patrimony of some fortresses from Romania, (Proceedings of the 5th WSEAS International Conference on Economy and Management Transformation Vol. I. Romania: University of Oradea (Department of Geography, Toruism, and Territorial Planning).

Dede, O.M. \& Ayten, A.M. (2012). The Role of spatial planning for sustainable tourism development: a theoritical model for Turkey. Tourism, 60(4), 431-444.

de Vaus, D.A. (1995). Survey in Social Research ( $4^{\text {th }}$ ed.). New South Wales: Ellen \& Unwin.
Dunkley, R., Morgan N. \& Westwood, S., 2011, Visiting the trenches: Exploring meanings and motivations in battlefield tourism, Tourism Management Vol. 32, pp. 860-868.

Eldin, S. S., Fekry, F. \& Menchawy, A. E., 2013, Abu Qir Fortresses as Vital Assets for Tourism Motivation and Community Development, Journal of Heritage Conservation Vol. 34, pp. 48-55.

Garaca, Jovanovic \& Pejovic, 2011, Petrovaradin Fortress (Novi Sad, Serbia): Tourism Spatial Planning and Design of The Upper Town for the Function of Cultural Tourism, Turizam Vol. 15: 2, pp. 65-76.

Goodchild, M.F. \& Longley, P.A. (13 July 2016). Citing Internet sources URL http://www.csiss.org/gispopsci/wor kshops/2005/PSU/docs/goodchild_ future.pdf.

Goyal, 2014, Educational Tourism: Analyzing the Global Trends, Asia Pacific Journal of Research Vol. I: XVIV, pp. 178-183.

GRAC, 2013, Daftar benteng di Indonesia: Wisata benteng (Menelusuri sejarah benteng di bumi nusantara).

Ismail, N., Masron, T. \& Ahmad, A., 2014, Cultural Heritage Tourism in Malaysia: Issues and Challenges, SHS Web of Conference 12, doi: 10.1051/shsconf/20141201059

Jovicic, D. \& Dragin, A., 2008, The Assessment of carrying capacity a crucial tool for managing tourism effects in tourist destinations, Turizam Vol. 12, pp. 4-11. 
Kuo, I-Ling, 2002, The Effectiveness of environmental interpretation at resource-sensitive tourism destinations. International Journal of Tourism Research, 4, pp. 87101.

Kurbanova, A.M. \& Gazalieva, N.I., 2014, Historical and cultural site of educaional tourism in Derbent City, World Applied Sciences Journal $30 \quad$ (Management, Economics, Technologies \& Tourism), pp. 224-226. DOI: 10.5829/idosi.wasj.2014.30.mett.4 4

Kurniawan, Novan Abdi \& Gunaan Sridiatmoko, 2015, Pemanfaatan Benteng Van der Wijck Gombong Kabupaten Kebumen Jawa Tengah sebagai sumber belajar dan objek pariwisata pendidikan, Yogyakarta: Universitas PGRI.

Loncarik, Buijana, 2013, Restoration of the Brod Fortress by the EU Funds, Croatia: Tourist Board Slavonski Brod.

Maksin, M. \& Milijic, S. (2010). Strategic planning for sustainable spatial, landscape and tourism development in Serbia. Spatium, 23, 30-37. DOI: 10.2298/SPAT10230M

Mansyur, S., 2008, Pengelolaan sumber daya arkeologi untuk pariwisata berkelanjutan, Kapata Arkeologi (Edisi Khusus Mei 2008), Ambon: Balai Arkeologi.

Marina, Lucian, Andreaa Muntean \& Claudiu Stefani, 2009, Development directions for the tourism offer of the Alba Iulia Fortress. Qualitative assessment. Annales Univesitatis Apulensis Series Oeconomica, Vol. 11 No. 2, 1041-1046.
Miles \& Huberman (1984) Miles, M. B. \& Huberman, A. M, 1984, Qualitative Data Analysis: A Sourcebook of New Methods. London: Sage Publications.

Mirsanjari, M. (2012). Importance of environmental ecotourism planning for sustainable development. International Journal of Sustainable Development, 4(2), 85-92.

Nahuelhual, L., Carmona, A., Lozada, P., Jaramillo, A. \& Mauricio. (2013). Mapping recreation and ecotourism as a cultural ecosystem service: an application at the local level in Southern Chile. Applied Geography, 40, 71-82.

Petroman, I., Petroman, C., Marin, D., Ciolac, R., Vaduva, L. \& Pandur, I., Types of cultural tourism, Animal Science and Biotechnologies Vol. 46(1), pp. 385-388.

Rukmana, Indra, 2015, Strategi pengelolaan museum benteng Vredeburg sebagai daya tarik wisata warisan budaya di Yogyakarta, Yogyakarta: ISI (Thesis).

Stanojlovic, A., Ivkov-Dzigurski, A. \& Dragin, A., 2010, The Lack of Interpretation at Fortresses along the Danube in Serbia, Geographica Timisiensis Vol. 19(2), pp. 185196).

Xie, P. F., 2006, Developing Industrial Heritage Tourism: A Case Study of the Proposed Jeep Museum in Toledo, Ohio, Tourism Management Vol. 27, pp. 1321-1330. doi: 10.1016/j.tourman.2005.06.010 